of the American Chemical Society. At the last meeting it was decided to establish a Remsen Memorial Collection, and an appeal has been issued for early portraits of Dr. Remsen, autographed letters on scientific subjects, and inscribed copies of the first, or an early, edition of his books, particularly books in a foreign language. Those who have memorabilia of this kind are requested to write to Dr. Lyman C. Newell, 688 Boylston Street, Boston, Mass.

\section{Science in Poland}

THE recent issue of vol. 14 of "Nauka Polska" (Science and Letters in Poland), published by the Institute for the Promotion of Science and Letters in Poland ( $\mathrm{J}$. Mianowski Funds, Warsaw, Staszic Palace. 1931), is in line with the former volumes of this publication. It contains several original articles on the organisation and progress of science in Poland, as well as in Germany, Hungary, Czechoslovakia, Yugoslavia, Spain, and the United States. One article gives a review of the professorial members of Polish State universities. News of scientific activities and congresses both in Europe and America and reviews of new books are also included.

\section{Science Abstracts ]}

Although the volumes of Science Abstracts for 1931 are slightly less than those for the previous year, they include a larger number of abstracts : in physics 4365 , of average length 0.254 page, and in electrical engineering 2697 , of average length 0.262 page, there having been a marked decrease in the latter figure from last year. Both author and subject indexes are ample, and the two volumes continue to be indispensable for reference.

\section{Announcements}

Ar the annual general meeting of the Society of Public Analysts, held on March 4, the following were elected as officers for the year 1932: President, F. W. F. Arnaud; Hon. Treasurer, E. B. Hughes; Hon. Secretary, G. Roche Lynch.

AT the annual general meeting of the Ray Society, held on March 10, the following officers were elected: President, Sir Sidney F. Harmer; Treasurer, Sir David Prain; Secretary, Dr. W. T. Calman. Sir J. Arthur Thomson, Prof. F. E. Weiss, and Mr. E. T. Browne were elected new members of Council. In the report of the Council it was announced that the second volume of "British Freshwater Copepoda" is in the press and will be issued to the subscribers for 1932 . It was also announced that Dr. R. W. T. Gunther has presented to the Society a portrait of his late uncle, Prof. W. C. M'Intosh. By permission of the President and Council of the Linnean Society, the portrait has been hung in the rooms of that Society.

In connexion with the Thomas Gray Memorial Trust, the objects of which are the advancement of the science of navigation and the scientific and educational interests of the British mercantile marine, the Royal Society of Arts, which founded the trust as a memorial to Thomas Gray, formerly assistant secretary to the Board of Trade (Marine Department), is again offering two prizes, each of the value of $£ 100$. One prize will be awarded for a valuable improvement in navigation proposed or invented in 1931 or 1932, and the other for an essay in connexion with navigatious. Further particulars can be obtained from the Secretary, Royal Society of Arts, John Street, Adelphi, London, W.C.2.

A Catalogue (No. 386) of nearly 3000 works relating to practically all branches of science, and a section on publications of the learned societies, has just been issued by Messrs. W. Heffer and Sons, Ltd., Petty Cury, Cambridge. It should be of interest to many readers.

AN item of particular interest to be included in the sale by auction by Messrs. Sotheby and Co., 34 New Bond Street, W.1, on March 21 and the following day is Michael Faraday's electrical plate machine, made to his order by E. G. Wood of Cheapside, 1830, and exhibited at the Faraday Centenary Exhibition in September last. The sale will also comprise some letters of Charles Darwin and F. T. Buckland, and a collection illustrating savage art, from Africa, America, Oceania, and New Zealand.

Applicatrons are invited for the following appointments, on or before the dates mentioned:-A sublibrarian of the Literary and Philosophical Society, Newcastle-upon-Tyne--The Librarian, Literary and Philosophical Society, Newcastle-upon-Tyne (March 28). A woman lecturer in mathematics at the Bingley Training College--The Education Officer, County Hall, Wakefield (March 30). A principal of the Sunderland Municipal Technical College-The Chief Education Officer, 15 John Street, Sunderland (April 9). A pathologist, a radiologist, and a pharmacist at the Southend-on-Sea New General Hospital-The Secretary, New General Hospital, Southend-onSea (April 10). A woman lecturer in biology at the Edge Hill Training College, Liverpool-The Principal, Edge Hill Training College, Liverpool (April 29). A demonstrator in physiology and a part-time demonstrator in geology at the Bedford College for WomenThe Secretary, Bedford College for Women, Regent's Park, N.W.1 (April 30). An assistant in the department of technology, City and Guilds of London Institute, for technical examination work, preferably with industrial knowledge, who has taught engineering or chemical subjects-The Superintendent, Department of Technology, City and Guilds of London Institute, 31 Brechin Place, S.W.7. A director under the International Tin Research and Development Fund, to organise and direct international research and development, with the object of expanding the existing markets for tin, and of finding new uses for the metal-Sir John Campbell, 2 Richmond Terrace, London, S.W.1. A professor of education and head of the men's training department of the University College of South Wales and Monmouthshire-The Registrar, University College of South Wales and Monmouthshire, Cardiff.

No. 3255, VoL. 129] 